RESEARCH Note

\title{
Bio-optical characterization of the waters of the Bay of La Paz, southern Gulf of California, during late spring 2004
}

\author{
Caracterización bio-óptica de la Bahía de La Paz, Golfo de California, durante fines de \\ primavera 2004
}

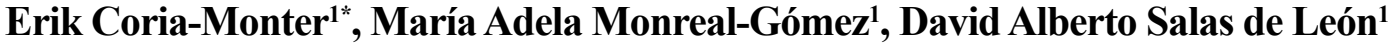 and Elizabeth Durán-Campos ${ }^{2}$}

\author{
'Unidad Académica de Ecología y Biodiversidad Acuática, Instituto de Ciencias del Mar y Limnología, Universidad Nacional Autónoma \\ de México, Av. Universidad 3000, Copilco, Del. Coyoacán, CP 04510, Cd. de México, México \\ ${ }^{2}$ Unidad Académica Mazatlán, Instituto de Ciencias del Mar y Limnología, Universidad Nacional Autónoma de México, Av. Joel Montes \\ Camarena s/n, CP 82000, Mazatlán, Sinaloa, México \\ *Corresponding author: coria@cmarl.unam.mx
}

\begin{abstract}
Information on selected bio-optical properties and primary production values of the waters of the Bay of La Paz, southern Gulf of California, is reported during June 2004, a region characterized to have very rich biodiversity, including endemic and endangered species, with high ecological relevance. In-situ measurements of natural fluorescence and photosynthetically available radiation (PAR) enabled the subsequent calculation of the incident irradiance $\left(E_{o}\right)$, the light extinction coefficient $(k)$, compensation depth $\left(Z_{c}\right)$ and critical depth $\left(Z_{c r}\right)$. The results suggest the presence of light propitious conditions for phytoplankton community growth and net primary production, which are highly significant for the potential development of models of light penetration, ocean color, primary productivity, and analyses of organic carbon energy flow.
\end{abstract}

Key words: Phytoplankton, bio-optical characterization, primary production, PAR measurements, Bay of La Paz

\section{INTRODUCTION}

The Bay of La Paz is the largest basin within the Gulf of California, located on the southwestern margin of the Baja California Peninsula of Mexico (Fig. 1a). The region is known to have very rich biodiversity, including endangered and endemic species, with high ecological relevance (Silverberg et al. 2014). The bay interchanges water masses with the gulf through two openings, Boca Grande (wide and deep) to the north, and San Lorenzo Channel (shallow and narrow) to the south, which generates important matter and energy flows between both environments (MonrealGómez et al. 2001).

In recent years, important efforts have been made to elucidate the processes that support the high biological productivity of the region, particularly regarding the planktonic ecosystem (Cervantes-Duarte et al. 2005). For instance, a close relationship between the presence of a mesoscale cyclonic eddy and phytoplankton community distribution has been observed, and it has been proposed that this eddy is a quasi-permanent feature of the area, and also an interesting case study of an eddy confined within a bay of biological significance, which in turn originates a differential phytoplankton distribution, where dinoflagellates dominate its center while diatoms dominate the periphery (Coria-Monter et al. 2014). The presence of this mesoscale eddy induces isopycnal uplifting (MonrealGómez et al. 2001) with an entrainment of subsurface nutrient-rich waters to the euphotic zone, which in turn promotes the primary productivity (Verdugo-Díaz et al. 2014). Changes in the structure of the phytoplankton functional groups has also been observed in the region as result of the seasonal variability, with a predominance of diatoms followed by dinoflagellates, the lasts to be dominant during the warm period (Verdugo-Díaz \& GárateLizárraga 2018).

The seasonal variability in the region is dominated by a water column stratified from June to September with a temperature of $\approx 27.5^{\circ} \mathrm{C}$, and by a well-defined mixed layer from October to May with a temperature of $\approx 18.5^{\circ} \mathrm{C}$, which in turn affect the marine phytoplankton community (Muciño-Márquez et al. 2018). This seasonal variability in the region is also close related with the wind field, which is mainly determined by the atmospheric shifting of the Pacific High Pressure Center and the Sonora Desert Low Pressure Center, resulting in northwesterly winds $(\approx 12 \mathrm{~m}$ $\left.\mathrm{s}^{-1}\right)$ during winter, and southeasterly winds $\left(\approx 5 \mathrm{~m} \mathrm{~s}^{-1}\right)$ during summer (Monreal-Gómez et al. 2001). 
Zooplankton functional groups respond to the relative vorticity induced by the cyclonic eddy confined to the bay, and the abundance of herbivorous zooplankton is directly correlated to the water density gradient imposed by the physical feature. An inverse correlation of carnivorous zooplankton abundance with water density was associated with negative vorticity outside the bay (Duran-Campos et al. 2015). More recently, Coria-Monter et al. (2017) reported that the physical forcing into the eddy field is the local wind, resulting in an upwelling, and promoting an increase in nutrient and chlorophyll- $a$ concentrations; this cyclonic circulation shows that joint effects of baroclinity and base topography play an important role in determining horizontal mass transport patterns, owing to buoyance forces. Winddriven upwelling occurs by means of an Ekman pumping velocity of $\approx 0.4 \mathrm{~m} \mathrm{~d}^{-1}$ at the base of the Ekman layer, which is responsible for the increase in productivity by means of nutrient transport into the euphotic zone available for phytoplankton.

Not only cyclonic eddies represent the principal mechanism of fertilization that characterize the Bay of La Paz (Martínez-López et al. 2016). Recently, based on insitu observations, Durán-Campos et al. (2019) documented the presence of a dipole structure (cyclonic-anticyclonic), which in turn originate a thermohaline front, and then an accumulation of the phytoplankton community. Additional large-scale processes, such as El Niño/La Niña and the Pacific Decadal Oscillation, were also recently associated with changes in the phytoplankton community in the region (Guevara-Guillén et al. 2018).
Although planktonic productivity in the region has been relatively well addressed, there have been major challenges in the field, particularly regarding the optical properties of the water column, which are essential for phytoplankton growth and productivity. As phytoplankton are the primary source of the marine food chain, they also control the carbon dioxide uptake by the ocean known as the biological pump and, then play a role in the global carbon cycle (Pieri et al. 2015). Evaluating the optical properties of the water column thus plays a key role in determine and understand variations in the fluxes of carbon and associated biogenic elements in the ocean (Platt \& Sathyendranath 1988). It is also crucial for the development of models of light transmission, with the light absorption in phytoplankton cells also driving photoautotrophic production in the ocean; then, studies on the changes in these parameters, as an indicator of phytoplankton physiologic, and their relationship with the environmental variability comes to be imperative (VerdugoDíaz et al. 2014). The optical properties of the water column are also essential for satellite ocean-color productivity, and exert a major effect on the whole planktonic ecosystem by controlling the biological radiation absorption and the availability of solar energy for photosynthesis (Takao et al. 2014).

This manuscript aims to asses and report, based on in-situ observations, selected bio-optical properties and primary production values of the water column of the Bay of La Paz, in the southern Gulf of California, with information gathered on a multidisciplinary research cruise during the late spring (June) of 2004. Measurements of natural fluorescence and a) Gulf of California

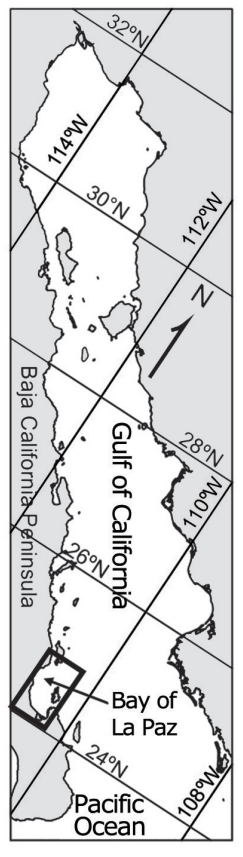

b) Bay of La Paz

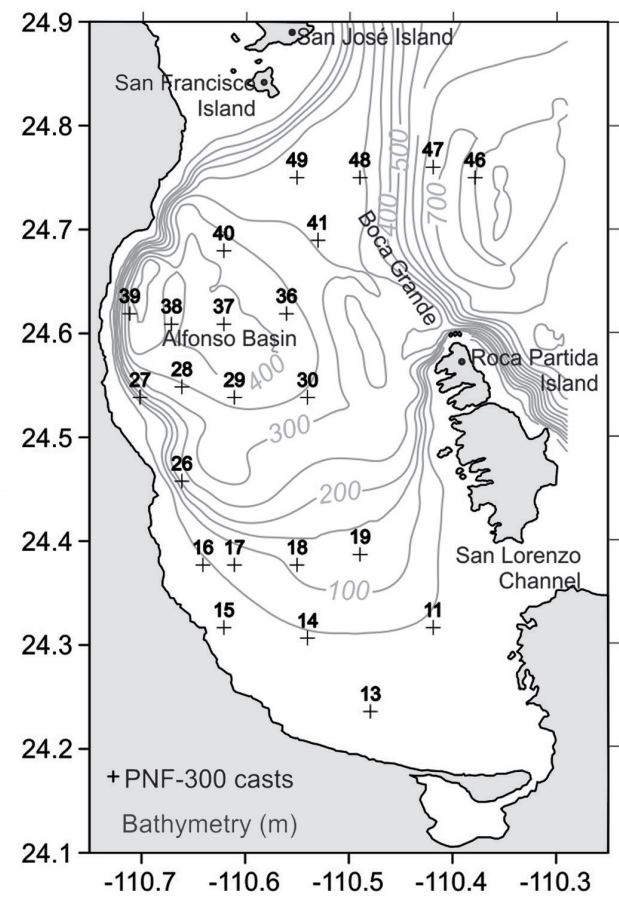

Figure 1. Study area: a) Gulf of California, the rectangle represents the sampling area; and b) Bay of La Paz, the black symbols represents the hydrographic stations / Área de estudio: a) Golfo de California, el rectángulo representa el área de muestreo; b) Bahía de La Paz, los símbolos negros representan las estaciones hidrográficas 
photosynthetically available radiation (PAR), enabled the subsequent calculation of the light extinction coefficient $(k)$, compensation depth $\left(Z_{c}\right)$ and critical depth $\left(Z_{c r}\right)$.

\section{MATERIALS AND METHODS}

Information was collected during the multidisciplinary research cruise "PALEO-XII", carried out from 14 to 18 June 2004 onboard the R/V "El Puma" of the Universidad Nacional Autónoma de México. Natural fluorescence, photosynthetically available radiation (PAR), and temperature were measured at 23 hydrographic stations (Fig. 1b), using a Profiling Natural Fluorometer (PNF-300) from Biospherical Instruments, previously calibrated by the manufacturer. This instrument measures the flux in natural fluorescence, which can then be used to estimate the instantaneous gross photosynthetic rate, while measurements

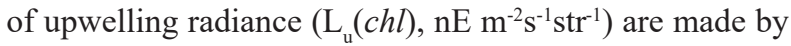
an optical sensor specifically over the emission spectrum of chlorophyll-a (Chamberlin et al. 1990). Based on this method, calculation of the chlorophyll concentration can be achieved via the coincident measurement of two optical variables: 1) the upwelling red radiance, which results from the fluorescence of the phytoplankton crop; and 2) the incident irradiance, which in turn drives photosynthesis. The equipment measured PAR over the spectral region from 400 to $700 \mathrm{~nm}$ using sensors with a flat quantum response. The chlorophyll- $a$ concentration ( $\mathrm{mg} \mathrm{m}^{-3}$ ) is thus calculated from the natural fluorescence flux $\left(F_{f}\right)$ and the incident irradiance following the protocols by Chamberlin et al. (1990), after removing the first $5 \mathrm{~m}$ of the water column due to the signal contamination by the sunlight, by the expression:

$$
C h l=\frac{F_{f}}{{ }^{\circ} a_{C}(\mathrm{PAR}) * \phi_{f} * E_{0}(\mathrm{PAR})}
$$

There are two important optical assumptions: 1$)^{\circ} a_{c}$ (PAR) is the chlorophyll-specific absorption coefficient (absorption normalized to chlorophyll concentration), and 2) $\varnothing_{f}$ is the quantum yield of fluorescence. These values were treated here as constants, such as in the software for the PNF-300, which assigned typical values of $0.04 \mathrm{~m}^{2} \mathrm{mg}^{-1}$ and 0.045 $\mu \mathrm{E}$ fluoresced per $\mu \mathrm{E}$ absorbed, respectively.

Fluorescence values were transformed to chlorophyll- $a$ concentration $\left(\mathrm{mg} \mathrm{m}^{-3}\right)$ using Equation 1, and were then integrated along the water column $\left(\mathrm{mg} \mathrm{m}^{-2}\right)$ according to the expression:

$$
\text { Chla }\left(m g \cdot m^{-2}\right)=\sum_{i=1}^{N}(\text { Chla }) i
$$

where Chla $\left(\mathrm{mg} \mathrm{m}^{-2}\right)$ is the chlorophyll- $a$ values vertically integrated and $N$ is the last differential of the profile and corresponds to the depth of integration.
Based on the PNF-300 measurements obtained, the average light extinction coefficient was also estimated in the water column $(k)$ according to Lalli \& Parsons (2006) and Falkowski \& Raven (2007) as:

$$
k=\frac{\ln \left(E_{0}\right)-\ln \left(E_{D}\right)}{z}
$$

where $E_{0}$ is the incident irradiance at water surface and $E_{D}$ is radiation at depth $z$, the last defined as the limit of the euphotic zone.

The compensation depth $\left(Z_{c}\right)$, defined as the depth at which gross photosynthetic carbon fixation balances phytoplankton respiratory losses over the course of one day, representing the lower boundary of the euphotic zone (Falkowski \& Raven 2007), was calculated via the expression:

$$
Z_{c}=\frac{\ln \left(E_{0}\right)-\ln \left(E_{c}\right)}{k}
$$

where surface radiation $\left(E_{0}\right)$ is measured directly by the equipment and $k$ is calculated using Equation 3. $E_{c}$ is the compensation light intensity, which varies with both the phytoplankton species and the light adaptation of any particularly species; values of $E_{c}$ range between 1 and 10 $\mu \mathrm{mol} \mathrm{m} \mathrm{m}^{-2} \mathrm{~s}^{-1}$ (Lalli \& Parsons 2006). Due to the absences of values as a baseline for the study area, in our particular case, a constant value of $5 \mu \mathrm{mol} \mathrm{m} \mathrm{m}^{-2} \mathrm{~s}^{-1}$ was assigned, following the criterion of Nelson \& Smith (1991) and Signoret et al. (2006), considering the case for waters from the Campeche Bay, Gulf of Mexico. The symbol $I$, which is sometimes used in older papers to denote irradiance, was not used here since it has been more recently adopted to denote radiation intensity, which is the flux of radiant energy per unit solid angle in a specified direction (Falkowski \& Raven 2007).

The critical depth $\left(Z_{c r}\right)$, defined as the depth at which the water column's integrated photosynthesis is equal to the integrated respiration, was calculated via the expression:

$$
Z_{c r}=\frac{0.5 E_{0}}{E_{c} k}
$$

where $E_{0}$ is the incident irradiance at water surface [here multiplied by 0.5 based on $50 \%$ photosynthetic active radiance, according to the criterion of Salas de León et al. (2004) and Signoret et al. (2006)], $E_{c}$ is the irradiance at the depth at which gross photosynthesis is equal to respiration, and $k$ is the extinction coefficient.

Using the PNF-300 data set, values of primary production were calculated following Kiefer et al. (1989) and Chamberlin et al. (1990), and then integrated from $5 \mathrm{~m}$ depth to the limit of the euphotic zone according to Cervantes-Duarte et al. (2005). Finally, based on the vertical distribution of temperature, the mixed layer depth was estimated using the depth of maximum temperature gradient $(\delta T / \delta z)$. 


\section{RESULTS AND DISCUSSION}

The calculation results revealed the presence of propitious conditions for phytoplankton community growth and net primary production at the time of our observations. Table 1 summarizes the selected optical bio-properties obtained and some weather conditions recorder during the cruise.

The values of $k$ have a significant effect on phytoplankton crop growth. In this study, $k$-values averaged 0.110 . Since $k$-values varies according to the wavelengths of light, values ranging from 0.035 to $0.140 \mathrm{~m}^{-1}$ have been reported by Lalli \& Parsons (2006), in agreement with our observations. Similar observations were reported by Salas de León et al. (2004) who found mean values of $k$ of 0.05 for waters of the southern Gulf of Mexico. According to Falwowski \& Raven (2007), values of $k$ could be potentially affected by the amount of chlorophyll contained in living phytoplankton and in plant debris or the dissolved and particulate matter along water column.

Our observations revealed mean values of $452 \mu \mathrm{mol} \mathrm{m}{ }^{-2}$ $\mathrm{s}^{-1}$ in the incident irradiance $\left(E_{0}\right)$; although values $>1,000$ $\mu \mathrm{mol} \mathrm{m} \mathrm{m}^{-2} \mathrm{~s}^{-1}$ on a sunny day have been reported in the literature (Kirk 2011), it is important to bear in mind that these depend on the time of the day that measurements are made, due to the sun's angle, and on the season as well as the latitude, so the values presented here are in agreement with those reported in regions at $\sim 20^{\circ} \mathrm{N}$ of latitude. For example, Salas de León et al. (2004) and Coria-Monter et al. (2019) reported values for the southern Gulf of Mexico ranging from 84.6 to $1061 \mu \mathrm{mol} \mathrm{m} \mathrm{m}^{-2} \mathrm{~s}^{-1}$.

In our study, $Z_{c r}$ varied from 4.8 to $27.7 \mathrm{~m}$; there are very few in-situ observations and consequent calculation of $Z_{c r}$ into the Bay of La Paz in the literature, and these are limited to the work of Cervantes-Duarte et al. (2005), who found values ranging from 41 to $80 \mathrm{~m}$, which seems higher than those reported in our study; however, they used a constant value of $35 \mu \mathrm{mol} \mathrm{m}{ }^{-2} \mathrm{~s}^{-1}$ for their $Z_{c r}$ calculation, while $5 \mu \mathrm{mol}$ $\mathrm{m}^{-2} \mathrm{~s}^{-1}$ was used as a constant value, following the criterion of Signoret et al. (2006) for regions located approximately at the same latitude, which set the differences in the values. The depth of mixed layers found in this study is in the same order of magnitude by those reported by Cervantes-Duarte et al. (2005) who found, using the maximum temperature gradient, mean values of $35 \mathrm{~m}$.

The chlorophyll- $a$ values observed along water column at the time of our observations ranged from 0.7 to $2 \mathrm{mg} \mathrm{m}^{-3}$ in agreement with those reported for the southern Gulf of California region, particularly the Bay of La Paz. Indeed, Coria-Monter et al. (2014) reported maximum values of 1.8 $\mathrm{mg} \mathrm{m}^{-3}$ during August, while Verdugo-Díaz et al. (2014) showed values of $2.51 \mathrm{mg} \mathrm{m}^{-3}$ during May in the Alfonso Basin. Gaxiola-Castro et al. (1999) reported a maximum of $2.75 \mathrm{mg} \mathrm{m}^{-3}$ in regions in the middle of the Gulf of

Table 1. Bio-optical properties of the waters of the Bay of La Paz, southern Gulf of California, during June 2004 with some weather conditions / Propiedades bio-ópticas en la Bahía de La Paz, durante junio de 2004 con algunas variables climáticas

\begin{tabular}{|c|c|c|c|c|c|c|c|c|c|c|c|c|c|c|c|c|c|}
\hline St & $\mathrm{Lat}^{\circ} \mathrm{N}$ & Lon $^{\circ} \mathrm{W}$ & $\begin{array}{c}\text { Time } \\
\text { GMT-7 }\end{array}$ & $\begin{array}{c}\mathrm{Z} \\
(\mathrm{m})\end{array}$ & $k$ & $E_{0}$ & $\begin{array}{c}Z c \\
(\mathrm{~m})\end{array}$ & $\begin{array}{l}Z_{c r} \\
(\mathrm{~m})\end{array}$ & $\begin{array}{l}\mathrm{EL} \\
(\mathrm{m})\end{array}$ & $\begin{array}{l}\text { ML } \\
(\mathrm{m})\end{array}$ & $\begin{array}{c}\mathrm{IChl} \\
\left(\mathrm{mg} \mathrm{m}^{-2}\right)\end{array}$ & $\begin{array}{l}\text { ChlMAX } \\
\left(\mathrm{mg} \mathrm{m}^{-3}\right)\end{array}$ & $\begin{array}{c}\text { DMC } \\
(\mathrm{m})\end{array}$ & $\begin{array}{c}\text { IPP } \\
\left(\mathrm{g} \mathrm{C} \mathrm{m}^{-2} \mathrm{~d}^{-1}\right)\end{array}$ & $\begin{array}{c}\text { TChla } \\
\text { MAX } \\
\left({ }^{\circ} \mathrm{C}\right)\end{array}$ & $\begin{array}{c}\text { WS } \\
\left(\mathrm{m} \mathrm{s}^{-1}\right)\end{array}$ & $\operatorname{Dir}\left({ }^{\circ}\right)$ \\
\hline 11 & 24.32 & 110.42 & $08: 25$ & 67 & 0.15 & 133 & 3 & 7.0 & 35 & 7 & 2 & 0.9 & 7.3 & 0.79 & 19.54 & 5.7 & 310 \\
\hline 13 & 24.24 & 110.48 & $11: 43$ & 27 & 0.13 & 420 & 11.2 & 5.0 & 27 & 10 & 6.6 & 1.1 & 9.8 & 2.45 & 20.01 & 3.9 & 276 \\
\hline 14 & 24.31 & 110.54 & $12: 53$ & 54 & 0.12 & 225 & 5.8 & 9.2 & 46 & 7 & 3.7 & 1.1 & 8.5 & 1.28 & 20.37 & 0.8 & 150 \\
\hline 15 & 24.32 & 110.62 & $14: 43$ & 33 & 0.10 & 61 & 16.1 & 6.7 & 33 & 5 & 3.3 & 0.7 & 10 & 0.52 & 20.31 & 0.3 & 306 \\
\hline 16 & 24.38 & 110.64 & $15: 51$ & 33 & 0.08 & 28 & 10.6 & 19.3 & 33 & 29 & 3.2 & 0.7 & 11.4 & 0.22 & 20.95 & 0.6 & 293 \\
\hline 17 & 24.38 & 110.61 & $17: 05$ & 70 & 0.18 & 291 & 3.3 & 6.1 & 44 & 15 & 5.0 & 1.0 & 5.3 & 1.23 & 21.72 & 2.0 & 244 \\
\hline 18 & 24.38 & 110.55 & $17: 50$ & 157 & 0.15 & 22 & 13.6 & 15.0 & 29 & 7 & 3.5 & 1.4 & 13.2 & 0.32 & 20.48 & 5.2 & 262 \\
\hline 19 & 24.39 & 110.49 & $19: 19$ & 215 & 0.17 & 14 & 9.2 & 11.6 & 24 & 21 & 2.2 & 0.7 & 14 & 0.09 & 19.68 & 3.2 & 321 \\
\hline 26 & 24.46 & 110.66 & $07: 51$ & 42 & 0.24 & 56 & 2.8 & 4.8 & 27 & 14 & 1.8 & 0.7 & 5 & 0.58 & 21.99 & 4.1 & 036 \\
\hline 27 & 24.54 & 110.70 & $10: 16$ & 62 & 0.16 & 247 & 4.3 & 6.8 & 47 & 13 & 3.1 & 1.0 & 8 & 0.82 & 21.20 & 4.2 & 044 \\
\hline 28 & 24.55 & 110.66 & $11: 47$ & 101 & 0.16 & 363 & 4.3 & 6.8 & 52 & 6 & 3.1 & 1.1 & 13 & 0.78 & 20.53 & 1.3 & 330 \\
\hline 29 & 24.54 & 110.61 & $14: 00$ & 330 & 0.16 & 517 & 4.3 & 6.7 & 50 & 7 & 2.0 & 1.0 & 13 & 0.97 & 18.80 & 3.1 & 267 \\
\hline 30 & 24.54 & 110.54 & $15: 59$ & 330 & 0.19 & 70 & 3.4 & 6.0 & 37 & 6 & 4.0 & 2.0 & 13 & 0.88 & 17.56 & 4.1 & 217 \\
\hline 36 & 24.62 & 110.56 & $07: 49$ & 345 & 0.20 & 89 & 4.0 & 6.0 & 33 & 10 & 4.4 & 1.1 & 12 & 0.41 & 18.88 & 6.7 & 321 \\
\hline 37 & 24.61 & 110.62 & $10: 24$ & 404 & 0.15 & 380 & 4.4 & 7.2 & 55 & 8 & 2.4 & 1.7 & 9 & 1.60 & 18.85 & 4.1 & 299 \\
\hline 38 & 24.61 & 110.67 & $12: 03$ & 220 & 0.14 & 359 & 33.3 & 27.7 & 55 & 9 & 1.1 & 0.9 & 11 & 0.68 & 20.78 & 5.7 & 049 \\
\hline 39 & 24.62 & 110.71 & $14: 56$ & 34 & 0.13 & 248 & 7.4 & 15.0 & 34 & 6 & 4.0 & 0.8 & 5 & 1.51 & 22.68 & 5.5 & 306 \\
\hline 40 & 24.68 & 110.62 & $15: 26$ & 405 & 0.12 & 31 & 20.4 & 21.0 & 47 & 9 & 1.8 & 1.0 & 11 & 0.17 & 20.15 & 2.8 & 234 \\
\hline 41 & 24.69 & 110.53 & $18: 11$ & 390 & 0.30 & 13 & 5.2 & 6.6 & 33 & 7 & 3.0 & 1.0 & 5 & 0.26 & 22.05 & 2.7 & 271 \\
\hline 46 & 24.75 & 110.38 & $07: 54$ & 835 & 0.17 & 28 & 2.5 & 6.5 & 27 & 12 & 3.0 & 0.7 & 26 & 0.02 & 22.13 & 1.8 & 328 \\
\hline 47 & 24.76 & 110.42 & $11: 03$ & 750 & 0.13 & 37 & 5.6 & 9.1 & 50 & 39 & 4.1 & 0.8 & 11 & 0.18 & 23.29 & 1.4 & 172 \\
\hline 48 & 24.75 & 110.49 & $13: 53$ & 170 & 0.16 & 484 & 3.8 & 6.7 & 52 & 22 & 1.4 & 0.9 & 5 & 1.17 & 23.18 & 0.4 & 317 \\
\hline 49 & 24.75 & 110.55 & $16: 54$ & 318 & 0.13 & 30 & 17.5 & 18.1 & 42 & 20 & 2.4 & 0.9 & 16 & 0.14 & 22.27 & 1.1 & 220 \\
\hline
\end{tabular}

$\mathrm{St}=$ number of station; Lat $=$ Latitude $\left({ }^{\circ} \mathrm{N}\right)$; Lon=Longitude $\left({ }^{\circ} \mathrm{W}\right)$; Time=GMT-7, Greenwich Mean Time-7; Z= total depth $(\mathrm{m})$; $\mathrm{k}=\mathrm{Average}$ extinction coefficient; $\mathrm{E}_{0}=$ Incident irradiance, $\left(\mu \mathrm{mol} \mathrm{m} \mathrm{m}^{-2} \mathrm{~s}^{-1}\right) ; \mathrm{Zc}=$ Compensation depth, $(\mathrm{m}) ; \mathrm{Zcr}=$ Critical depth, $(\mathrm{m}) ; \mathrm{EL}=$ Euphotic layer thickness, $(\mathrm{m}) ; \mathrm{ML}=\mathrm{Mixed}$ layer, $(\mathrm{m}) ; \mathrm{Chl}$ $\left(\mathrm{mg} \mathrm{m}^{-2}\right)=$ integrated chlorophyll- $a$ values; ChlMAX $\left(\mathrm{mg} \mathrm{m}^{-3}\right)=$ chlorophyll- $a$ maximum values; DCM= deep chlorophyll- $a$ maximum, $(\mathrm{m})$; IPP $=$ Integrated Primary Production $\left(\mathrm{g} \mathrm{C} \mathrm{m}^{-2} \mathrm{~d}^{-1}\right)$; TChlaMAX $=$ Temperature at ChlaMAX $\left({ }^{\circ} \mathrm{C}\right)$; WS $=$ Wind speed $\left(\mathrm{m} \mathrm{s}^{-1}\right)$; Dir $=$ wind direction $\left({ }^{\circ}\right)$ 
California. Similar values have been also reported for the water of the southern Gulf of Mexico by Durán-Campos et al. (2017), using PNF-300, who found mean values of $0.8 \mathrm{mg} \mathrm{m}^{-3}$. The chlorophyll- $a$ vertical distribution in three representative stations along the bay (stations \# 15, 30 and 40 ), showed the maximum values close related with the thermocline and the peaks into the euphotic zone (Fig. 2).

The values of the chlorophyll- $a$ vertically integrated in our study rose to range from 1.1 to $6.6 \mathrm{mg} \mathrm{m}^{-2}$, in agreement with those reported by Martínez-Lopez et al. (2001) who found values of $\sim 10 \mathrm{mg} \mathrm{m}^{-2}$ in the summer.

The integrated primary production values, obtained from the PNF-300 data set, were in a range from 0.02 to $2.45 \mathrm{~g} \mathrm{C} \mathrm{m}^{-2} \mathrm{~d}^{-1}$, in agreement with those reported by Cervantes-Duarte et al. (2005) who showed maximum values of $2.26 \mathrm{~g} \mathrm{C} \mathrm{m}^{-2} \mathrm{~d}^{-1}$ into Bay of La Paz during June.

It is also clear from Table 1 that, in all stations, the chlorophyll- $a$ maximum are into the euphotic layer, showing properly conditions for photosynthesis, and thus the production of phytoplankton. Statistical analyses were performed in order to test the significance levels. For example, a significance correlation $(R=0.61, P=0.0001)$ was found between temperature and the chlorophyll- $a$ levels, while the significance between the mixed layer and the integrated primary production values was $R=0.33, P$ $=0.0001$.

To our knowledge, very few in-situ measurements of the optical properties of the water column in the Bay of La Paz have been reported, and the information available is limited to the works of Reyes-Salinas et al. (2003), Cervantes-Duarte et al. (2005) and Verdugo-Díaz et al. (2014), who showed a significant spatial and seasonal variability in the photosynthetic parameters and the primary production levels in the region, with the existence of two seasons in the primary production cycle: one of high primary production values from March to August; another one of low primary production values from September to February. Gaxiola-Castro et al. (1999) reported a strong seasonal and interannual variability in the photosynthetic parameters along the Gulf of California, related to the presence of hydrodynamic processes (such as fronts), which in turn modify the thermohaline structure of the water column.

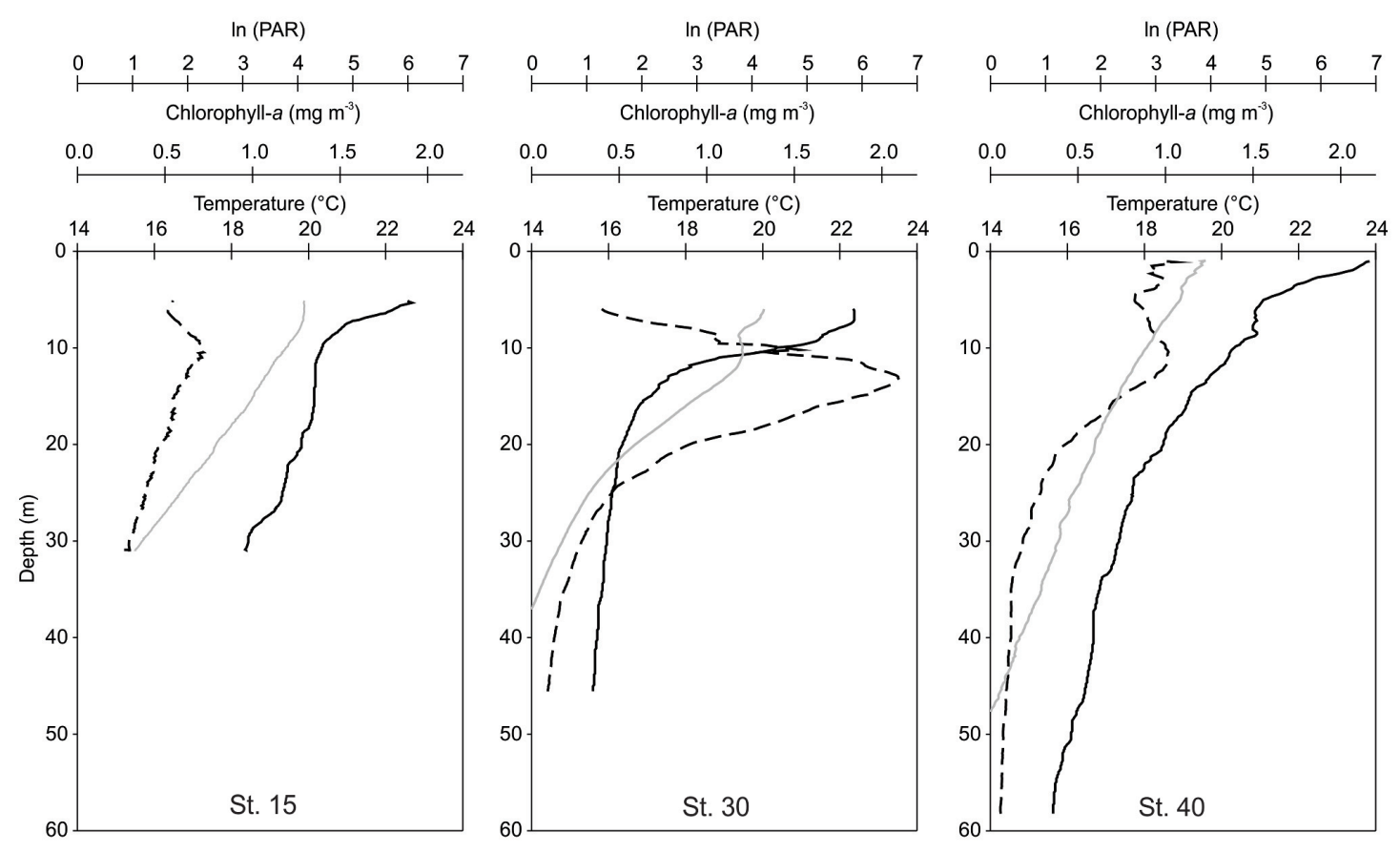

Figure 2. Vertical profiles of temperature $\left({ }^{\circ} \mathrm{C}\right)$ (solid black line), chlorophyl- $a\left(\mathrm{mg} \mathrm{m}^{-3}\right)$ (black medium dash line) and PAR (solid gray line) in three stations (\# 15, 30 and 40) along the Bay of La Paz / Perfiles verticales de temperatura $\left({ }^{\circ} \mathrm{C}\right)$ (línea contínua negra), clorofila- $a\left(\mathrm{mg} \mathrm{m}^{-3}\right)$ (línea punteada negra) y PAR (línea contínua gris) en tres estaciones (\# 15, 30 y 40) a lo largo de la Bahía de La Paz 
The results reported here are highly significant for the bio-optical properties of Bay of La Paz, regarding the potential development of models of light penetration, ocean color and primary productivity in the region. The data could also be used to examine the interannual variability of heterotrophic processes such as the energy flow from autotrophs to heterotrophs, as well as for future analyses of organic carbon energy flow. Many more detailed in-situ observations regarding the optical properties of the water column in the Bay of $\mathrm{La} \mathrm{Paz}$ are required to establish the possible seasonal variation in these parameters, which are linked not only to circulation patterns but also to the nutrient concentrations available to phytoplankton. The region is known to be subject to a wide seasonal variability, and due to its location near the connection to the open Pacific Ocean, the site is a sensitive record of regional variations in the gulf and the larger scale climate circulation of the subtropical Pacific Ocean. One of the major sources of interannual and monthly variability in the southern gulf, and consequently the Bay of La Paz, has been connected to the El Niño/Southern Oscillation (ENSO) (Pérez-Cruz 2013), which in turn modifies the hydrographic conditions of the water column, as already discussed.

\section{ACKNOWLEDGMENTS}

The ship time for the research cruise PALEO-XII on board the R/V El Puma was funded by the Universidad Nacional Autónoma de México (UNAM). The authors would like to thank all the participants of the research cruise, including the captain and crew. F. Sergio Castillo Sandoval provided technical support during the analyses. We appreciate numerous helpful comments by three anonymous reviewers.

\section{LITERATURE CITED}

Cervantes-Duarte R, G Verdugo-Díaz \& JE Valdez-Holguín. 2005. Seasonal model of primary production estimated by natural fluorescence in a coastal region of the Gulf of California. Hidrobiologica 15(1): 79-87.

Chamberlin WS, CR Booth, DA Kiefer, JH Morrow \& RC Murphy. 1990. Evidence for a simple relationship between natural fluorescence, photosynthesis, and chlorophyll in the sea. Deep-Sea Research Part A 37: 951-973.

Coria-Monter E, MA Monreal-Gómez, DA Salas de León, J Aldeco-Ramírez \& M Merino-Ibarra. 2014. Differential distribution of diatoms and dinoflagellates in a cyclonic eddy confined in the Bay of La Paz, Gulf of California. Journal of Geophysical Research Oceans 119: 6258-6268.

Coria-Monter E, MA Monreal-Gómez, DA Salas de León \& E Durán-Campos. 2017. Wind driven nutrient and chlorophyll- $a$ enhancement at a cyclonic circulation in Bay of La Paz, Gulf of California, Mexico. Estuarine, Coastal and Shelf Science 196: 290-300.

Coria-Monter E, DA Salas de León, MA Monreal-Gómez \& E Durán-Campos. 2019. Optical properties of the waters of the southern Gulf of Mexico during summer. Latin American Journal of Aquatic Research 47(3): 568-574.
Durán-Campos E, DA Salas de León, MA Monreal-Gómez, J Aldeco-Ramírez \& Coria-Monter. 2015. Differential zooplankton aggregation due to relative vorticity in a semi-enclosed bay. Estuarine, Coastal and Shelf Science 164: 10-18.

Durán-Campos E, DA Salas de León, MA Monreal-Gómez \& E Coria-Monter. 2017. Patterns of chlorophyll-a distribution linked to mesoscale structures in two contrasting areas Campeche Canyon and Bank, Southern Gulf of Mexico. Journal of Sea Research 123: 30-38.

Durán-Campos E, MA Monreal-Gómez, DA Salas de León \& E Coria-Monter. 2019. Impact of a dipole on the phytoplankton community in a semi-enclosed basin of the southern Gulf of California, Mexico. Oceanologia 61(3): 331-340.

Falkowski PG \& A Raven. 2007. Aquatic photosynthesis, 484 pp. Princeton University Press, New York.

Gaxiola-Castro G, S Álvarez-Borrego, MF Lavín, A Zirino \& S Nájera-Martínez. 1999. Spatial variability of the photosynthetic parameters and biomass of the Gulf of California phytoplankton. Journal of Plankton Research 21(2): 231-245.

Guevara-Guillén C, B Shirasago-Germán, EL PérezLezama \& M Obeso-Niebla. 2018. Variability of chlorophyll a concentration and halocline depth in La Paz Bay (Gulf of California, Mexico) and the relationship to Pacific large-scale phenomena. Journal of Coastal Research 34(4): 920-927.

Kiefer DA, WS Chamberlin \& CR Booth. 1989. Natural fluorescence of chlorophyll a: relationship to photosynthesis and chlorophyll concentration in the western South Pacific gyre. Limnology and Oceanography 34: 868-881.

Kirk JTO. 2011. Light and photosynthesis in aquatic ecosystems, 649 pp. Cambridge University Press, New York.

Lalli CM \& TR Parsons. 2006. Biological oceanography: An introduction, 314 pp. Elsevier, Butterworth-Heinemann, Woburn.

Martínez-López A, R Cervantes-Duarte, A Reyes-Salinas \& JE Valdez-Holguín. 2001. Cambio estacional de clorofila a en la Bahía de La Paz, B.C.S., México. Hidrobiológica 11(1): 45-52.

Martínez-López A, IG Álvarez-Gómez, L Pérez-Cruz, G Verdugo-Díaz \& MM Villegas-Aguilera. 2016. Production, exportation and preservation of silicoflagellates in Alfonso Basin, Gulf of California. Journal of Sea Research 109: 52-62.

Monreal-Gómez MA, A Molina-Cruz \& DA Salas de León. 2001. Water masses and cyclonic circulation in Bay of $\mathrm{La}$ Paz, during June 1998. Journal of Marine Systems 30: 305-315.

Muciño-Márquez RE, I Gárate-Lizárraga, DJ LópezCortés, JJ Bustillos-Guzmán \& FE HernándezSandoval. 2018. Seasonal variation of the phytoplankton community in tuna farms in Bahía de La Paz, southern Gulf of California, Mexico. Latin American Journal of Aquatic Research 46(5): 1011-1024.

Nelson DM \& WO Smith Jr. 1991. Sverdrup revisited: Critical depths, maximum chlorophyll levels, and the control Southern Ocean productivity by the irradiance-mixing regime. Limnology and Oceanography 36(8): 1650-1661. 
Pérez-Cruz L. 2013. Hydrological changes and paleoproductivity in the Gulf of California during middle and late Holocene and their relationship with ITCZ and North American Monsoon variability. Quaternary Research 79: $138-151$

Pieri M, L Massi, L Lazzara, C Nuccio, C Lapucci \& F Maselli. 2015. Assessment of three algorithms for the operational estimation of [CHLA] from MODIS data in the Western Mediterranean Sea. European Journal of Remote Sensing 48: 383-401.

Platt T \& S Sathyendranath. 1988. Oceanic primary production: estimation by remote sensing at local and regional scales. Science 241: 1613-1620.

Reyes-Salinas A, R Cervantes-Duarte, RA Morales-Pérez \& JE Valdez-Holguín. 2003. Seasonal variability of primary productivity and its relation to the vertical stratification in La Paz bay, B.C.S. Hidrobiológica 13(2): 103-110.

Salas de León DA, MA Monreal-Gómez, M Signoret \& J Aldeco-Ramírez. 2004. Anticyclonic-cyclonic eddies and their impact on near-surface chlorophyll stocks and oxygen supersaturation over the Campeche Canyon, Gulf of Mexico. Journal of Geophysical Research 109: C05012, $<$ doi.org/10.1029/2002JC001614>
Signoret M, MA Monreal-Gómez, J Aldeco \& DA Salas de León. 2006. Hydrography, oxygen saturation, suspended particulate matter, and chlorophyll- $a$ fluorescence in an oceanic region under freshwater influence. Estuarine, Coastal and Shelf Science 69: 153-164.

Silverberg N, F Aguirre-Bahena \& A Mucci. 2014. Time-series measurements of settling particulate matter in Alfonso Basin, La Paz Bay, southwestern Gulf of California. Continental Shelf Research 84: 169-187.

Takao S, T Iida, T Isada, SI Saitoh, T Hirata \& K Suzuki. 2014. Bio-optical properties during the summer season in the Sea of Okhotsk. Progress in Oceanography 126: 233-241.

Verdugo-Díaz G \& I Gárate-Lizárraga. 2018. Distribution of functional groups of phytoplankton in the euphotic zone during an annual cycle in Bahia de La Paz, Gulf of California. CICIMAR Oceánides 33(1): 47-61.

Verdugo-Díaz G, A Martínez-López, MM Villegas-Aguilera \& G Gaxiola-Castro. 2014. Producción primaria y eficiencia fotosintética en Cuenca Alfonso, Bahía de La Paz, Golfo de California, México. Revista de Biología Marina y Oceanografía 43(3): 527-536.

Received 21 March 2019 and accepted 27 September 2019

Editor: Claudia Bustos D. 